Yury Fogelson, Dmitry Poldnikov*

\title{
The Social History of Law as a Factor of the Rule of Law ${ }^{1}$
}

\begin{abstract}
:
The rule of law, understood as ideology and legal rules, is believed to be a competitive advantage of Western civilization, supporting its sustainable development. Yet it can also be viewed as a social norm of citizens who respect the law and follow its commands. How does this social norm emerge in different societies? This question must be answered through the social history of the law in Western and non-Western societies from a comparative perspective.

This paper outlines the main features of comparative socio-legal history and tests it on some significant historical examples. In the first part of the article, the authors propose a functional classification of legal systems into three ideal Weberian types - the law of judges, learned law, and the law of the authorities. It allows us to consider the origin of the social norm of the rule of law. In the second part of the article, the authors trace the transition from the ideal types to natural legal systems and identify the factors that determine the stability of the social norm of the rule of law where it originated.

In the final part of the article, the authors conclude that, first, the social norm of the rule of law emerged in the societies where the law had been treated either as a means of resolving disputes (the law of judges) or as the rules of fair, correct conduct (learned law), for example, the Roman Republic, medieval England, continental Europe, and the Ottoman Empire. Secondly, the stability of the social norm of the rule of law seems to be explained by a "triangle" of factors, namely: 1) political competition where all participants understand the inevitability of compromise on the basis of the law, 2) law which is suitable for finding a compromise due to its internal merits, 3) a professional community of jurists who develop and apply law independently of the administration. Such a triangle is possible in any society where the law of judges or learned law prevails and where the majority of participants in the political process are ready to compromise based on the current law. / JEL Classification: K 10; K 11; K 12
\end{abstract}

Keywords: rule of law, social norm, comparative socio-legal history, law of judges, learned law, law of the authorities

* Yury B. Fogelson, Research Professor: Faculty of Law / School of Legal Regulation of Business, National Research University Higher School of Economics, Doctor of Sciences in Civil Law e-mail: yfogelson@hse.ru;

Dmitry D. Poldnikov, Professor of legal history at the Department of general and inter-branch legal disciplines, Faculty of Law, National Research University 'Higher School of Economics' (Moscow), e-mail: dpoldnikov@hse.ru.

1 This publication was prepared with the support of the Faculty of Law of the Higher School of Economics within the framework of the project group "Social History of Law as a factor in ensuring the Rule of Law" of the Higher School of Economics in 2020 and with the informational support of the company "ConsultantPlus". 


\section{Introduction}

One of the most important elements of good governance today is the rule of law and the state of justice. It is an ideology which the elites of Western civilization use to promote their influence in various spheres of public life and geopolitics. ${ }^{2}$ The influence of this ideology in the world is so ubiquitous that even the major competitors of the Western countries cannot ignore it. For example, the Chinese Communist Party included Article 5, on the administration of the country in accordance with the law, in the Constitution of 1982. It is not difficult for an attentive reader to notice that Article 5 is more about the rule-by-law than about the rule-of-law, as this Article does not bind the Chinese Communist Party. Nevertheless, it is notable how the Constitution recognises the value of law (or rather legislation) after its wholesale dismissal during the Cultural Revolution.

In contemporary Russia, lawmakers also actively use the rhetoric of the rule of law. At least, Article 1 of the Russian Constitution explicitly defines Russia as a democratic state governed by the rule of law, and the significance of such self-identification is not questioned in either doctrinal or judicial interpretation.

There are multiple examples of non-Western political and academic elites building on the ideology of the rule of law. Many of them aspire to transplant not only the language but also the infrastructure of the rule of law: developed legislation, the protection of human rights, the separation of powers and everything related to this. However, few have managed to achieve the same effect of the rule of law as Western nations. What is missing? The rule of law is not only an ideology and infrastructure, but, first of all, the legal consciousness of citizens, their trust and respect for the law, the internal desire to comply with the law despite any possible short-term benefits of bending it.

Some sociologists of law coined the concept of the "social norm of the rule of law"3 to mark that "the general demand for conformity is insistent and the social pressure brought to bear upon those who deviate or threaten to deviate is great". ${ }^{4}$ In Western countries, this social norm was developed in social life, and in this sense, we can talk about the social history of law as a factor in the effectiveness of the rule of law. Other communities are believed to be deprived of this social norm, or at least, the degree of its normativity is far from desirable, which many scholars call "legal nihilism". For example, Russian society is widely believed to be nihilistic. In the western

2 The academic literature on this topic is vast. A search of the Google Books global publication database using the $\mathrm{N}$-gram Viewer tool clearly indicates a spike in the frequency of rule of law use in literature since the mid-1980 s and an almost twofold increase by the end of the 2010 s. https://books.google.com/ngrams/graph?content\&year_start $=1800 \& y e a r \_e n d=2000$ $\&$ corpus $=0 \&$ smoothing $=3 \&$ direct_url $=$. See also https://trends.google.com/trends/explore? $\mathrm{cat}=7 \&$ date $=$ all $\& \mathrm{q}=\% 2 \mathrm{Fm} \% 2 \mathrm{~F} 0 \mathrm{jqv}$ (accessed 11.6.2020).

3 See, for example, Licht A. N. (2008) Social norms and law: why people obey the law / / Review of Law and Economics. Vol. 4, Issue 3. P. 715-750, Acemoglu D., Jackson M. O. Social norms and law enforcement. April 2017. Journal of the European Economic Association 15(2), P. 245-295.

4 See Hart H. L. A. The concept of law, 2nd edn, Oxford University press, 1994, p. 86. 
literature it has become almost a truism, included in textbooks ${ }^{5}$ and supported with references to judicial practice, opinion polls, the image of law in the media and literature. ${ }^{6}$ Today it is not so easy to find (or express!) in foreign publications a different point of view. ${ }^{7}$

The internal consensus of Russian legal scholars on this issue is even more noticeable. Many would subscribe to a series of short theses: legal nihilism exists, it is a brake on development, and it is an old problem. ${ }^{8}$

We will not dwell on the correctness of the term "legal nihilism", which denotes the absence of a social norm of the rule of law in society, ${ }^{9}$ since this would lead us away from the purpose of this paper. Let us only emphasize that the stability of the rule of law in a particular society largely depends on how the members of that society decide whether or not to act according to the law. And this, in turn, depends on their preferences. You can imagine that each person making such decisions has a set of scales to weigh this or that decision and act accordingly. It is easy to imagine the social norm of the rule of law as a weight on these scales. In the societies where this weight exists, people act according to the law because their scales tell them so. Where the social norm of the rule of law has not developed, people may also act according to the instructions of these scales. But the scales often do not require a person to act in accordance with the law.

In order to understand how the social norm of the rule of law arises in societiesthis weight on the scales of decision-making - it is necessary to trace the social history of law in different societies. This formidable task cannot be achieved in one article.

5 Thus, the author of one of the recent fundamental German textbooks on comparative law devotes no more than five pages (out of a thousand!) Russian law, whose main problem he calls legal nihilism as a legacy of the Soviet past. (Uwe Kischel, Rechtsvergleichung / Comparative Law, 544-545).

6 See, for example, Nußberger, Angelika, Die Frage nach dem tertium comparationis-Zu den Schwierigkeiten einer rechtsvergleichenden Analyse des russischen Rechts, in: Recht in Ost und West 42 (1998), 81 (83); Brunner, Georg, Rechtskultur in Osteuropa-Das Problem der Kulturgrenzen, in: Brunner, Georg(ed), Politische und ökonomische Transformation in Osteuropa, 3rd edn 2000, 111(120 f) (as a Consequence of Soviet Domination); Image and Experience of Law (joint Franco-Russian sociological study).

7 Borisova, Tatiana, and Jane Burbank. "Russia's legal trajectories". Kritika: Explorations in Russian and Eurasian History 19.3 (2018), p. 469-508; Russia, Europe, and the rule of law, ed. by F. Feldbrugge. Martinus Nijhoff Publishers; 2007, p. 203-216.

8 Here are just a few statements of recent years. At the end of the Soviet period, V.A. Tumanov wrote about "legal nihilism". In recent years, a number of dissertations and monographs have supported the following theses: "Legal nihilism has deep historical roots, being a characteristic feature of the Russian mentality" (V. N. Gulyikhin); "It seems obvious to me that the society to which I belong, and the culture in which I grew up and was formed, is characterized by a negative attitude to law, approaching its complete denial" (S.P. Shevtsov). Many modern Russians still consider their compatriots to be law-abiding (as studies led by K. Handley have shown).

9 One of the authors of this article has considered this issue in detail. See Fogelson Yu. B. The model of the Russian "homo legalis" and the stability of the order based on the rule of law // Proceedings of the Institute of State and Law of the Russian Academy of Sciences, 2020, vol. 15 , no. 4 , pp. 81-108. 
The purpose of this study is to set up the parameters of such an approach and to take the first steps along this path.

Since we are talking about society's attitude to law, in the first part of the article, we classify legal systems according to the function that law performs in the society, i.e. we offer a functional classification of legal systems. The result of this classification are three ideal types (in the sense of Max Weber), ${ }^{10}$ based on specific historical examples, which allow us to see the birth of the social norm of the rule of law. In the second part of the article, we move from ideal types to actual legal systems and identify the factors that determine the stability of the social norm of the rule of law in the societies where it originated.

\section{A functional typology of legal systems: three ideal types}

People's attitude to law has varied through history and they are used in more than one way. In a schematic manner, we can differentiate between three basic functions: ${ }^{11}$

1) law as a means for dispute resolution,

2) law as the rules of fair or correct behaviour,

3) law as an instrument with which the government maintains the social order it considers necessary.

Obviously, this classification is ideal in the sense that these functions may be mixed. However, in some societies, the law actually performs only or mostly one of the functions listed above.

\section{The law of judges $^{12}$}

Where the law was seen only as a means for dispute resolution, legal norms were created when people went to court. Those seeking to resolve a dispute had to decide whether it was worth the court's attention and what the facts to be considered were. This required professional lawyers who decided questions of law, while questions of fact, not requiring professional knowledge could be considered by ordinary people who are best familiar with the situation. Today we call such people jurors. The main problem for the parties in such legal systems was to convince the court to admit their case for examination. For this purpose, "forms of action" were created. If a dispute arose and it did not match any of the forms of action, the court did not examine it.

10 Max Weber on the methodology of the social sciences, ed. by E.A. Shils, H.A. Finch. Glencoe, Ill.: The Free Press, 1949, p. 93.

11 By "law" we mean a set of written rules that are systematically applied similarly to similar cases and therefore the result of their application is predictable. These norms are effective, i.e. the consequences of their application are realized in real life. There are societies where the rules known to people, even written ones, are the starting point for negotiating disputes, see, for example, Rosen L. The Anthropology of Justice, Cambridge, 1989. We do not consider such cases here, since for such systems the very concept of "rule of law" is meaningless.

12 Usually the law of judges is called Anglo-American common law, but we used this term by analogy and for the law of republican Rome because of the fact that the ways of creating and applying law in these legal systems are very similar. 
However, as society developed, more disputes arose that did not strictly fit into any of the forms of action and the courts had to find a way to expand the list of admitted claims. We can call these forms of action the true legal rules since the enforceability of claims depended on these forms. From such a perspective, no one invented legal rules; they arose from social interaction and disputes, while the courts only implemented them.

Two legal systems match this type: the law of the Roman Republic and English common law from the Constitutions of Clarendon of King Henry II (1164) to the outbreak of the Hundred Years' War in 1337.

The Roman Republic. It is believed that the beginning of Roman law was laid by the conflict between the patricians and the plebeians over the unfair - in the opinion of the plebeians - justice administered by the patricians. ${ }^{13}$ This conflict was resolved by creating the Law of the Twelve Tables, which were, in fact, the first collection of legal claims. Theodor Mommsen describes its significance as follows: "The real political significance of the measure resided less in the contents of its legislation than in the formal obligation now laid upon the consuls to administer justice according to its forms of procedure and its legal rules, and in the public exhibition of the laws which subjected the administration of justice to the public control, and the consul was compelled to dispense equal and truly fair justice to all". ${ }^{14}$

Since 367 BCE, the people's assemblies began to elect special magistrates (praetors), who introduced the civil process according to formulas from the middle of the 3 rd century BCE. If there was a conflict, a Roman citizen went to the praetor and presented his case in any format and language. The praetor checked the validity of the claims, established a formula for this conflict, appointed a private arbiter to decide, as we now say, questions of fact. In time, new kinds of conflicts arose between people, and the praetors used their powers to expand the list of formulas accordingly and to announce them in praetor's edicts. In the first half of the 2nd century CE, Emperor Hadrian ordered the consolidation of all such edicts into one "Perpetual Edict". ${ }^{15}$

The popularity of the civil procedure by formulas stimulated the emergence of jurists. They mastered the analysis of legal cases sometime around the first half of the 2nd century $\mathrm{BCE}^{16}$ and proceeded until the creation of the Corpus Iuris Civilis in the 6th century CE. Well-known jurists gave their opinions (responsae) in complex cases which influenced dispute resolution and expanded the list of legally protected interests. All this activity, as well as the whole life of the Roman Republic, took place under the control of the patricians, represented by the Senate and consuls; and the plebeians, led by the tribunes of the people. As a result, it prevented arbitrariness in judicial administration.

Sooner or later, peoples subjected to Rome realized the value of reliable legal protection and sought to obtain Roman citizenship. According to the German historian Karl Christ, "The ancient world does not know of a state in which the individual citi-

13 For this narrative see: Livius T., The History of Rome, ed. by D. Spillan, London, 1854. Vol. 1. Book $3,33 \mathrm{f}$.

14 Mommsen, T. History of Rome. London: Bentley, 1862 Vol. 1, p. 291.

15 See: Berger, A. Encyclopedic dictionary of Roman law. NY: American Philosophical Society, 1953. p. 449.

16 Ibid. p. 474-475. 
zen was so effectively protected from the abuses of state power as in the classical Roman republic". 17

One episode in the Acts of the Apostles illustrates this: "But when they had stretched him out for the whips, Paul said to the centurion who was standing by, 'Is it lawful for you to flog a man who is a Roman citizen and uncondemned?' When the centurion heard this, he went to the tribune and said to him, 'What are you about to do? For this man is a Roman citizen.' So, the tribune came and said to him, 'Tell me, are you a Roman citizen?' And he said, 'Yes.' The tribune answered, 'I bought this citizenship for a large sum.' Paul said, 'But I am a citizen by birth.' So those who were about to examine him withdrew from him immediately, and the tribune also was afraid, for he realized that Paul was a Roman citizen and that he had bound him" (Acts 22:25-29). ${ }^{18}$ Roman citizens knew nothing about the rule of law, but if there was a conflict, they went to the officials with jurisdiction and were sure that they would find protection there. In this legal system, the social norm of the rule of law sank roots naturally.

English common law. This originated mostly from the Constitutions of Clarendon of King Henry II of $1164 .{ }^{19}$ At this point, two ordinary secular jurisdictions co-existed in England, public (county courts) and private (courts of the landholder of a manor), alongside the ecclesiastical jurisdiction. The royal jurisdiction was extraordinary. The county courts had virtually no enforcement powers, while the landlords and the church did. The landlords and the Catholic Church also sought to expand their jurisdictions at the expense of royal power. ${ }^{20}$ King Henry II carried out a reform of the royal justice, significantly limiting the manorial and ecclesiastical jurisdictions.

The main features of this and subsequent reforms are as follows:

- for a small number of serious crimes, the exclusive royal jurisdiction was maintained;

- for the rest of the cases, there were clearly listed types of claims to be considered by the king's justices; while some cases were in the exclusive jurisdiction of the crown, and for others, the plaintiff could apply to the king's court, or could apply to another secular jurisdiction, or, if the proceedings began in another jurisdiction, could ask for it to be transferred to the king's court;

- the plaintiff sought a hearing in the king's court, indicating the applicability of the relevant type of claim;

- having obtained a hearing and paid a fee, the plaintiff received a writ from the Lord Chancellor, addressed to the sheriff (the king's highest official in the county); the order contained the form of action and obliged the sheriff to perform a number of procedural actions and, if necessary, to use coercive powers;

17 Christ, K., Geschichte der römischen Kaiserzeit: von Augustus bis zu Konstantin. München: CH Beck, 2009. S. 59.

18 Acts of the Holy Apostles, cited after English standard version at https://www.biblegatewa y.com/passage $/$ ?search $=+20 \% 3 \mathrm{~A} 4-23 \% 3 \mathrm{~A} 35 \&$ version=ESV.

19 Select Historical Documents of the Middle Ages / transl. end ed. by E.F. Henderson London, 1905, P.P.11-16. Also available URL: https://archive.org/details/selectdocuments00he nd/page/n35/mode/2up.

20 For more information, see Pollock, F. Maitland, F. W. History of English Law to the Time of Edward I. 2nd edn. Vol. 1. Cambridge: Cambridge university press, 1899, p. 39-42. 
- the remaining questions of fact were to be decided by a jury of twelve knights who knew the situation on the ground well, so that the dispute was resolved as if by itself;

- finally, three royal courts were created: the King's Bench, the Court of Common Pleas and the Court of Exchequer located in Westminster, as well as periodic courts with itinerant justices which were to be held around the kingdom. ${ }^{21}$

In order to get a writ, the plaintiff applied to the Lord Chancellor directly or, later, to one of the Westminster courts or to an itinerant justice. In the address, the plaintiff must state his claims and indicate an appropriate form of action. The king's judge either agreed and began the trial or dismissed the plaintiff's claim as falling outside his jurisdiction. A description of the forms of procedure in the king's courts and the corresponding forms of action can be found in the treatise presumably written by Henry II's Chief Justiciar Ranulf de Glanvill. ${ }^{22}$ This collection is considered the first register of the forms of action. ${ }^{23}$

The number of the forms of action grew throughout the 13th century. In the collection sent to the Irish Chancery in 1227 , its number significantly exceeded those listed in Glanvill. ${ }^{24}$ At first, the Lord Chancellor created new forms of action at his discretion, but in 1285, the second Statute of Westminster limited this activity to "cases similar to those that already exist". New forms of action had to be introduced with the consent of Parliament. However, from time-to-time justices heard new disputes (super casum) on their own motion in order to grant legal protection in the absence of a pre-existing form of action.

This legal development created a need for lawyers. Special Inns of Court (professional associations) were established, four of which survive today. Lawyers acquired professional skills there. Although the king appointed judges from the most experienced lawyers, they actually retained their professional independence as the introduction of the new forms of action was controlled by Parliament.

The king's justice became popular with the lower classes. Until the 15 th century, the serfs (villeins) had to settle their disputes in the manorial courts of their landlord. However, the Soviet medievalist Yevgeniya Gutnova investigated the records of the royal courts of the 12 th to 14 th centuries and convincingly showed that the villeins often addressed the king's courts to protect them from their landlords. ${ }^{25}$ Glanvill introduced forms of action for recognising someone as a free person. The villeins could benefit from such claims as well as from king's courts for the poor, where no money was taken for issuing a writ.

English common law, like Roman law, gave individuals legal status and therefore gained popularity not only among free persons who used it to defend themselves

21 Pollock F. Maitland F. W., Op. cit. Vol. I. P.155 - 156.

22 The Treatise on the Laws and Customs of the Realm of England Commonly Called Glanvill. - Oxford, 1998.

23 Van Caenegem R. C. The Birth of the English Common Law. - Cambridge, 1973, p. 30.

24 Pollock F. Maitland F. W. Ibid. Vol. I, p.171.

25 Gutnova E. $V$., English common law and the peasantry in theory and in practice (12th to 14th centuries), in: Srednije veka, 1986, issue 49, p. 26-40. 
against those more powerful and influential but even among the most dependent peasants.

\section{Learned law or the law of scholars}

When people regard the law as the rules of fair or correct behaviour, they are guided by some standard of correctness or justice. It can be found in sacred texts, such as the Quran and Sunnah in Muslim law or the Torah in Jewish law or the Corpus Iuris Civilis as written reason (ratio scripta) based on the medieval Roman-canon law (ius commune). However, these primary sources are not enough to meet the needs of a changing society. There is often a professional group of interpreters, legal scholars, who develop methods and techniques to derive new rules from the primary sources.

We will briefly consider here two such legal systems: Muslim law from the beginning of its development by the Prophet to the moment when the work of independent scholars (ijtihad) was limited, and Roman canon law which developed at universities of medieval continental Europe from the 12th to the 17th centuries.

The law revealed by Allah. The Prophet Muhammad began his preaching in 610 $\mathrm{CE}$, and about 30 years later the Bedouin tribes of the Arabian Peninsula, who had never known a united governance or customs ${ }^{26}$ formed a new religious society (Ummah) with a theocratic form of government (caliphate). ${ }^{27}$ The entire life of a faithful Muslim is defined by the prescriptions of two sacred sources - the Quran and the Sunnah of the Prophet. ${ }^{28}$ This path of a righteous life is called Sharia. Its authority is based on the divine texts - the Quran and the Sunnah of the Prophet - that came from Allah, not from humans, which gives Sharia the highest degree of authority.

Sharia is eternal and unchangeable, but life goes on and new problems arise. For Muslims, the rules for the daily life (called fiqh) are also important. Some of the rules of fiqh can be derived from the Quran and the Sunnah. For example, to establish paternity, the minimum period of pregnancy is important. The Quran says that childbearing and breast-feeding lasts for thirty months, ${ }^{29}$ and the Quran also says that breast-feeding lasts for two years. ${ }^{30}$ A simple calculus (subtracting 30-24 =6) shows that the minimum period of child-bearing is six months. But there are only a few 'readymade' legal rules in the sacred texts, so, Muslim scholars created particular techniques to deduce the rules of fiqh from the sacred texts.

Islamic scholars believed that the sacred texts were created in such a way that one could understand them through reason and be guided in exactly the same and similar situations. ${ }^{31}$ Finding rules for similar situations is called qiyas - deduction by analogy

26 By 661, the caliphate occupied not only all of Arabia, but also Egypt and the Persian state of the Sassanids, and some of the former southern provinces of Byzantium, including Syria, Palestine, and Mesopotamia. By 750, the whole of North Africa, including Tunisia and Morocco, as well as Andalusia, were annexed to this territory.

27 For more information, see Vagabov M. V., Objective conditions and subjective factors of the emergence of Islam, in: Islamovedenie, 2010, No. 1, p. 10.

28 The Sunnah of the Prophet is the life of the Prophet, his actions and sayings.

29 The Qu'ran Surah 46 ayat 14. Here and further references to the Quran are given by The Quran English meaning / Al-Muntada Al Islami, 2004.

30 The Quran Surah 31 ayat 13.

31 Weiss, B.G., The spirit of Islamic law (Vol. 5). University of Georgia Press, 1998, p. 53-54. 
based on the intention. For example, the Quran reads: "Do not approach prayer while you are intoxicated, until you understand what you are saying". ${ }^{32}$ This leads to the conclusion: when praying, you need to understand what you are praying about; intoxication prevents this, and, therefore, is prohibited. Similarly, smoking marijuana is prohibited as it makes the mind unclear.

However, like any formal method, qiyas can lead to inconvenient results. For example, the Sunnah contains the following saying of the Prophet: "Whoever sells food should not do so until he has it in his own possession". On the basis of this saying, it was prohibited to sell future things. ${ }^{33}$ This prohibition slowed down trade and outlawed what everyone had been doing for a long time. To correct such situations, another method of reasoning (called "istikhsan") was invented. It allowed jurists to prioritise one of the interests protected on the basis of analogy. Istikhsan helped to correct the prohibition to sell things that the seller did not have at the moment of entering into the contract. There were other methods to derive new fiqh-rules. Jurists who were able to deduce new rules (fatwas) from the holy texts of the Quran and Sunnah were called mujtahids. The process of producing new fatwas, called ijtihad, received the approval of the Prophet himself. ${ }^{34}$

This did not, however, solve the problem of predictable dispute resolution. Under the law of judges everyone knew or could find out, after consulting a lawyer, which rights were protected and which were not, because the formulas of action were more or less stable and the rule of following the precedents (stare decisis) was introduced later. Muslim law welcomed the divergence of opinions of the mujtahids as a manifestation of the mercy of Allah. ${ }^{35}$ It paved the way for several schools (madhhabs) of Islamic law, four of which survive among Sunni Muslims today. On many issues, all schools had a common opinion, and this was a sign that the true law had been found. However, there were also disagreements. Public authorities sought to eliminate them. For instance, the Caliph Harun Al-Rashid suggested the founder of one of the madhhabs, Imam Malik, make his fiqh the official law in the Caliphate, but Imam strongly rejected this idea. ${ }^{36}$ It was inconvenient for people of the same region to adhere to the teachings of different schools. As a result, the successors of the Caliphate adopted the fiqh of one of the four remaining madhhabs. The "gates of the independent ijtihad were closed" 37 and the jurists of a particular madhhab began to use the fatwas of the most prominent mujtahids of their madhhab, rather than the sacred texts, to resolve new kind of disputes.

The Ius commune in medieval Europe arose from the needs of the citizens of independent cities for transparent and fair rules of civil transactions. It required the study of the Digest of Justinian at the turn of the 11th century in Bologna on the initiative of private scholars who offered classes in Roman law to all interested students. The Bo-

32 The Quran Surah 4 ayat 46.

33 Philips, A.A.B., Evolution-of-Fiqh. IslamKotob. 1988, p. 68-69.

34 Ibid p.44.

35 The Prophet said: "Whoever makes a reasoned decision (Ijtihaad) and is correct will two rewards while he who does so and is incorrect will receive one reward". Philips, A.A.B., Op. cit., p. 41.

36 Philips, A.A.B., Op. cit. p.127.

37 Schacht J., An Introduction to Islamic Law, Oxford, 1986, p. 69-71. 
logna law school was made possible by three main components: 1) an authoritative text, 2) a scholastic method of its interpretation, 3) a professional community of interpreters.

The discovery of the Digest, Codex, Institutions, and Authentica (the Latin translation of the new decrees) of Justinian at the end of the 11th century provided the Bologna professors with a "legal Bible"—an undisputable, perfect, and complete piece of legislation. Medieval jurists started to call it the Corpus of civil (Roman) law, or the complete collection of legal rules for the citizens of the Roman Empire.

The first jurists of Northern Italy approached this text in the same way as theologians interpreted Holy Scripture. The goals of interpretation were to understand the law through the text; to resolve all the visible contradictions in it; to establish connections and order between disparate fragments. With the help of formal logic, the jurists chose a fragment to study, identified its contested meanings, then tried to clarify them with the help of arguments "pro" and "contra" with references to other fragments of the Corpus of Justinian, and, finally, suggested an acceptable interpretation, free from contradictions.

Scholastic understanding of the text could be learned only by participating in the debates about the meaning of the fragments of the Corpus under the guidance of scholars who determined the standards of student training, issued teaching licenses and recruited new teachers into the ranks of their corporation, following the example of other professional guilds. ${ }^{38}$ The main result of this scholastic study of Roman law was the doctrine - a comprehensive, rational teaching about the sources of law, rights and duties, and due process for resolving disputes and restoring justice.

The political struggle between the Holy Roman Empire and the Roman Catholic Church at the turn of the 11th century made this teaching popular with both secular and ecclesiastical authorities. ${ }^{39}$ Each authority needed legal arguments to justify its supremacy in Christendom, effective administrators, and legal procedures. In the mid 12 th century, the study of ecclesiastical canons began in Bologna. This helped the Catholic Church to become the first organization in Europe whose leadership used rational legal procedures and institutions to unite the church lands and parishes scattered around Europe.

Secular law also changed, especially where citizens sought self-government (coupled with jurisdiction). The statutes of the most self-governed cities (communes) allowed their judges to adjudicate on the basis of expert opinions (consilia). These consilia - especially the answers of well-known doctors of law-indicated the "general opinion", which became an important argument for judges and a source of city (statutory) law. That is why the number of consilia increased rapidly and they circulated in various collections in the 14 th through 16 th centuries. ${ }^{40}$

38 A history of the university in Europe, vol. 1, ed. by H. de Ridder-Symoens. Cambridge, 2003, p. 388-408.

39 On the legal consequences of this struggle see: Berman H., Law and revolution, Cambridge, Mass: Belknap, 1983.

40 The famous commentator Bartolus gave over 400 opinions. His pupil Baldus left over 2500. See: Horn N. Die legistische Literatur der Kommentatoren, in: Handbuch der Quellen und Literatur der neueren Europäischen Privatrechtsgeschihte, H. Coing (ed.), vol. 1. München: C.H.Beck, 1973, p. 336. 
Where cities did not have independence, royal power facilitated the borrowing of the ius commune by employing, from the 13th century, officials with legal education who used learned law as a means to strengthen the crown's influence and to limit private seigniorial jurisdictions. ${ }^{41}$ The population came to prefer the more authoritative and predictable royal justice to feudal courts. ${ }^{42}$

The most valuable and long-lasting impact of the ius commune was the "scholarly" approach to the interpretation and application of all other sources of positive law. It gave European jurists a unique tool to develop (and, in fact, to create new) law without the involvement of public authorities. It also established the idea of justice not as a spontaneous or irrational process of finding a suitable solution in oral customs, but as the rational decision-making of professional judges, justified by references to written law and applied with due process. ${ }^{43}$

\section{The law of the authorities}

The Chinese Model: Legalism and Confucianism. Apparently, senior state officials of Ancient China were the first to substantiate the possibility of managing society by means of man-made legislation. In the literature, this discovery is usually attributed to the ideology of legalism during the Warring States period (5th to 3rd centuries BCE) and the formation of the first Chinese empire of Qin (3rd century BCE). ${ }^{44}$ Actually, the law of the authorities could be the result of the combined elitist ideology of the Legalists and Confucians implemented by state officials in an agricultural country where the majority population was deprived of any influence on politics.

Until the 20th century, the Chinese language lacked an adequate term for "law". The closest match was the term "(penal) law" $(f a)$. Thanks to the legalist officials of the Warring States period (Shang Yang, Shen Buhai, Han Fei, and others), the concept of law and punishment almost merged. The legalists believed in the vicious nature of people who could be governed only by authoritarian and cynical ruler, bureaucracy and punitive law.

Confucius (551-479 BCE), on the contrary, believed that people were good by nature and only need to be taught to follow the rituals (li) and benevolence (ren). The

41 See: Martinez Martines F., When Europe was unified. Ius commune, Italian style, French style, and Castilian supplement, in: Ivs Antiquum, 2005. N. 2 (16), p. 143-162; Dawson J.P. The oracles of the law. Ann Arbor: The University of Michigan, 1968; Wieacker F., A history of private law in Europe with particular reference to Germany, translated and edited by T. Weir, Oxford, 1995.

42 See: Dawson J.P., op. cit., p. 138-147 (on Italy), p. 196-213 (on Germany), p. 339-350 (on France); Padoa-Schioppa A., A History of Law in Europe: From the Early Middle Ages to the Twentieth Century. Cambridge, 2017, p. 307-319 (with further references); Carbasse J.-M., Histoire du droit pénal et de la justice criminelle. 3 e ed. Paris, 2014. p. 141-176 (with further references).

43 Müßig U., Reason and fairness: constituting justice in Europe, from medieval canon law to ECHR. Leiden: Brill, 2019, chapters 1 and 2.

44 For example, Perelomov L.S., Confucianism and Legalism in the Political History of China, Moscow, 1981; Bodde D., China's first unifier: a study of the Ch'in Dynasty as seen in the life of Li Ssu (280? - 208 BC). Hongkong, 1967; Yuri Pines et al. Birth of an Empire: the state of Qin revisited. Berkeley, CA, 2014. 
latter did not mean the humanism of the European Renaissance, but a strict and unshakable hierarchy in the state and society: "Let the ruler be the ruler, the subject be the subject, the father be the father, the son be the son". Confucius and his followers sharply criticized the legalists' approach. ${ }^{45}$

Perhaps the Legalists and Confucians did not see their teachings as compatible. However, they were combined in the official ideology during the Han Dynasty (206 BCE-220 CE). Emperor Wu Di (141-87 BCE) proclaimed the law $(f a)$ to be a sanction for each violation of the rituals $(l i)$. This gave impetus to the formation of the law of the authorities in the imperial China.

Its main features are as follows:

- extensive criminal and administrative legislation;

- justice administered by officials, not professional judges, without the participation of lawyers (the legal profession was outlawed as a means to discourage litigiousness among the people); ${ }^{46}$

- adjudication only in the form of a criminal procedure (for example, a creditor could demand a debt be repaid only by accusing his debtor of criminal fraud); ${ }^{47}$

- encouraging people to settle their disputes amicably via mediation rather than through legal procedure (for example, the Kangxi emperor (1654-1722) once openly stated: "I wish that those who come to court be treated without any pity, so that they would experience the deepest aversion to the law and be afraid to appear before an official". ${ }^{48}$

The peculiarities of the law of the authorities forced the population of China to avoid official justice and gave rise to the dualism of official law and the customs of families, village communities, corporations, and clans. This dualism was especially noticeable to outsiders. An Austrian traveller wrote in 1898: "Knowledgeable people assured me that Chinese legislation is excellent and so clear, precise, and correct that no

45 For example, when in 536 BC. the adviser to the ruler of the kingdom Zheng Zi Chan promulgated the laws on metal plates, Confucius criticized the decision: "he put aristocrats and slaves on the same level! How will dignity now motivate aristocrats to act virtuous? " He is also credited with the words: "there are those in the world who know how to solve litigations no worse than me, but I try to resort to punishments as rarely as possible".

46 One of the articles of the Tang Code, for the sake of eradicating litigation, threatened them with criminal liability and thereby hindered the development of the legal profession. Historians managed to find references to the activities of a few corporations of law clerks from Shaoxin (about $200 \mathrm{~km}$ south of Shanghai), who consulted the participants in the process, but they could not compare with officials in terms of number and social status. See : H. McAleavy, Chinese law, in: Introduction to legal systems, ed. by J. Derrett. London, 1968. p. 125.

47 One of the collections of the 13th century included the case of a dispute between a porter of salt and a porter of brushwood over who owned the lamb skin for carrying the load. Judge Lee Hoi told the aides, "Torture the hide and we will find out the truth!" The skin was spread on the ground and they began to beat on it with a stick. Soon, grains of salt came out of it, and the porter of the brushwood confessed that he was telling a lie ("Collection of court cases under a pear tree". XIII century. Cited after: Malyavin V.V., Chinese civilization, Moscow, 2000. p. 138).

48 Cited after: McAleavy H., op. cit. p. 115. 
European code can match it. [... However] the deepest fear of the Chinese of the courts is caused by the behaviour of the corrupt and negligent officials and cruelty of torture and punishment. This is why the Chinese decide to go to court only when there is no other option. You may think that all the legal proceedings are deliberately designed that way to make the Chinese to settle their disputes amicably". 49

Russia before the abolition of serfdom. Almost all Russian positive law from Ivan III (1462-1505) to the reforms of Alexander II in the $1860 \mathrm{~s}$ was essentially the law of the authorities. Until the reign of the Grand Duke of Moscow, Ivan III, the law in the Russian principalities was customary. ${ }^{50}$ However, at the end of the 15 th century, Ivan III managed to extend his power over a vast territory and needed uniform rules to govern it. This brought about the enactment of the Lawbooks of 1497 and 1550 as well as other written positive laws.

The legal norms in the Lawbooks (Sudebnik in Russian) were clearly the will of the sovereign. Article 98 of the Lawbook of 1550 illustrates this: "And if new kinds of cases arise which have no relevant provisions in this Lawbook, these must be reported to the prince who will resolve them together with all the boyars (i.e., the feudal nobility), and the new rule is to be inscribed into this Lawbook". ${ }^{2}$ These are the words not of a compiler of customs, but of an actual legislator who exercised authority to create and abolish legal norms. Another example would be the famous article 57 of the Lawbook of 1497: "And Christians (peasants) may leave their region and migrate from village to village only once a year, a week before St. George's Day in Autumn and a week after it". ${ }^{2}$ Everything we know about St. George's Day in Autumn and the migrations of peasants clearly indicates the will of the sovereign who enacted an entirely new rule, rather than borrowing it from custom or established practice.

The attitude of the authorities to the law they enacted was purely utilitarian. The main purpose of this law was - as Vasily Klyuchevsky wrote-"to involve everyone in the performance of work for the state and to regulate strictly people's labour in the interests of the treasury". ${ }^{53} \mathrm{He}$ concluded: "the legislation elaborates not the limits and conditions of serfdom as a right, but only the methods to exploit the serf labour, and to do so in two ways: fiscally by the treasury and economically by the landowner". ${ }^{54}$ It remained this way for at least three more centuries.

49 From the notes of the Austrian traveler Ernst von Hesse-Warteg, "China and the Chinese" (1898). Cited after: Malyavin V.V.,op. cit., p. 140.

50 A well-known expert on Russian law, I.D. Belyaev, wrote about Russian law of the 11 th 15th centuries: "At the time being described, there was no complete positive law, the law was expressed in customs. Therefore, the princes only formulated or canceled the established custom". See Belyaev I. D., Lectures on the history of Russian legislation / Preface. A. D. Kaplin / Ed. ed. O. A. Platonov. - M., 2011, p. 172.

51 Monuments of Russian law: Monuments of law of the period of strengthening of the Russian centralized state, XVI-XVII centuries. Issue 4 / Ed by. L. V. Cherepnin. - M., 1956, p. 260.

52 Monuments of Russian law: Monuments of law of the period of formation of the Russian centralized state, XIV-XV centuries. Issue 3 / Ed. L. V. Cherepnina. - Moscow, 1955, p. 355.

53 Klyuchevsky V.O., Works in 9 volumes. Vol.3. Russian history course. Part 3 / Ed. V. L. Yanin. - M., 1988, p. 148..

54 Klyuchevsky V.O., Works in 9 volumes. Vol.4. Russian history course. Part 4 / Ed. V. L. Yanin. - M., 1989, p. 93. 
Although the law created by the state formally applied to the whole population, the peasants lived according to their own customs and faced the law only when committing serious crimes. In the words of Nikolai Druzhinin, a researcher of the legal status of Russian peasants: "The most striking aspect of serfdom was undoubtedly the non-interference of the law and the authorities in the relationship between landowners and peasants". ${ }^{55}$ This brought about legal dualism: "The powers of the landowner separated the peasants from the state and the law with a wall". ${ }^{56}$ The peasants were judged in the private jurisdiction of the landowner; they were judged according to unwritten customs, not the law. Their attitude to landowners' courts is evident from their statements, preserved for us by the Ethnographic Bureau of Vyacheslav Tenishev. One of the bureau's correspondents narrated the following story: "The victim said in conclusion that all this was forged by the clerk who also interrogated the witnesses and instructed the judges how to resolve the case. How did he pass on his instructions? Before the judges (of the landowner's court) gather for consultations, he writes on a piece of paper "Dismiss (the claim)!" in block letters, and the chairman is a little literate and reads it" 57

In countries with the law of the authorities, the population avoided the law and there was no impetus for the emergence of the social norm of the rule of law.

\section{Transition from ideal types to reality}

Roman law becomes imperial law. The troubled times of the Roman Republic began with a violation of the law. It is hard to say who committed it first. Appian believed that the rich violated the order ${ }^{58}$ as they appropriated more land than the land law allowed. ${ }^{59}$ Theodor Mommsen wrote that it was Tiberius Gracchus who first broke the law by forcibly dismissing his fellow magistrate. ${ }^{60} \mathrm{Be}$ that as it may, at the end of the 2nd century BCE a conflict broke out in Rome. Soon it escalated into civil war and it was not possible to extinguish it for more the century and a half. The driving forces were the parties of Optimates and Populares (today we call them populists). These names reflect the aspirations of the parties to this conflict: the Optimates (the best citizens or, as we now say, the elite) sought to preserve the old republican order and live by the law, while the Populares found support from impoverished Romans who keenly desired to "take everything away from the rich and share it fairly". As a result, the Populares won, and Rome transformed itself into an empire after the civil wars.

55 Druzhinin N.P., Legal status of peasants. - SPb., 1897, p. 18.

56 Shatkovskaya T.V., Legal life of Russian peasants in the second half of the XIX century: dis.... PhD in hist. - Rostov-on-Don, 2000, p. 102.

57 Tenishev V., Justice in Russian peasant life. Ed. 2nd. - Moscow, 2011, p. 16.

58 Appian's Roman History with an English transl. by Horace White. In Four Volumes, Vol. III (1964), Harvard University Press, p. 17.

59 The Law Licinia - Sextia on the land maximum, which prohibited the acquisition of more than 500 yugers, a fine (some write that this is approximately 250 hectares, while others, that it is approximately 125 hectares) of public land and a serious violation was established. See: Berger, A. op. cit., p. 556. Some question the very existence of such a law, since 500 yugers for those times was an exorbitant value for a land plot. See Sergeev V. Op. cit. p. 71.

60 Mommsen, T., op. cit. Vol. III, p. 91-92. 
Under the new regime, imperial constitutions and decrees were recognized as the sources of the law and "police jurisdiction" was introduced. ${ }^{61}$ Nevertheless, Roman jurists continued to develop the law from the 1 st to the mid 3rd century CE. This was the period when the most notable jurists were active, including Julian, the compiler of the "Perpetual Edict", Papinian, Paul, Ulpian, Gaius, the author of the well-known Institutions (textbook), as well as many other jurists known to us from the Digest of Justinian. From then on, many notable jurists performed duties in the imperial service and their activities were controlled by the emperors (for example, Julian was provincial governor in Germany and consul, Papinian and Ulpian were praetorian prefects). ${ }^{62}$ Still, Roman law was not transformed into the law of the authorities and Roman citizenship was still valued.

However, it became less valuable in the 3rd century. In 212, the emperor Caracalla granted full Roman citizenship to most free men of the empire. Cassius Dio observed this and made the following remark: "It seemed to be a great honour, but the emperor's real purpose was to increase his tax revenues, as non-citizens did not pay most of the taxes". ${ }^{63}$ The emperors needed more money to wage war and to maintain law enforcement.

The financial reforms of Diocletian and Constantine at the turn of the 3rd century substantially increased taxes on ordinary citizens. According to Karl Christ, "Constantine's state was a state with a heavy taxation burden, corrupt officials, exploited citizens and restricted freedom". ${ }^{64}$ Book XI of the Code of Justinian preserved several constitutions of that period that forbade poor farmers (called coloni), workers of mines and weaving factories to leave their place of work. As a reaction to such hardships, entire villages of small farmers moved themselves under the patronage of large landowners in order to receive protection from the state. ${ }^{65}$ In the 4 th to 5 th centuries such farmers lost their legal status. According to the constitution of the emperors Arcadius and Honorius: "We deny this kind of people the right to sue their protectors and patrons in civil matters". 66 "This kind of people" found themselves in the private jurisdiction of their masters, and the legal status of most of the population of the empire lost its meaning. About a century before Justinian's codification, Presbyter Salvian wrote: "the status of Roman citizenship used to be so valued and acquired at steep price, but now (people) neglect and avoid it, and hold it for being worthless and almost abhorrent". ${ }^{67}$ The social norm of the rule of law, which arose in the Rome Republic and existed for some time in the Roman Empire, was lost.

61 Christ K., Op. cit. p. 116.

62 The emperors' control over the jurists was tight. When Papinian refused to prepare a legal basis for the emperor's murder of his brother, the emperor killed him. See Dio's Roman History with an English transl. By Earnest Cary. In Nine Volumes. Vol. VIII London, New York (1914) p. 287.

63 Dio, op. cit. p. 297.

64 Christ K., Op. cit. P.473.

65 For details on patrocinias, see Sergeev V.S., Essays on the history of ancient Rome in 2 parts / Part II, M., 1938, p. $699-702$.

66 C. Just. XI, 50.2.4.

67 The Fathers of the Church. Vol.3 The writing of Salvian the Presbiter. CUA Press (2008), p.136. 
English common law holds up well. In England, the period from the beginning of the Hundred Years' War (1337) to the beginning of the reign of the Tudors (1485) was a period of turmoil and, just as in Rome, it paved the way for stronger royal power. However, the king could not impose his absolute control over the country as Parliament retained its strength and influence.

The credibility of royal justice by this time was greatly shaken ${ }^{68}$ and Henry VII began to rebuild it in cooperation with Parliament. He reformed the Privy Council and established the Star Chamber and several other extraordinary courts. Parliament assisted the king. In the words of Winston Churchill: "[The Council] was given the Parliamentary authority to examine persons with or without oath and condemn them on written evidence alone in a manner foreign to the practice of the Common Law. The Court of the Star Chamber met regularly in Westminster [...] the complaints of the weak and the oppressed against the rich and mighty, cases of retainer which involved keeping of private armies of liveried servants, and of embracery, which meant corruption of juries - all these became their sphere". ${ }^{69}$

Many plaintiffs went not to court but to the king, and it was the Lord Chancellor who dealt with their petitions for "mercy and equity". Until the mid-16th century the Lord Chancellor was almost always a churchman well-versed in canon law, so he made his decisions on the basis of written evidence, "mercy and equity", and Roman canon law, which by that time had become the standard of justice on the Continent. Henry VII reformed the Lord Chancellor by establishing - in addition to the common law courts - the Chancellery Court for regular hearings of such petitions for equity. It allowed for the emergence of a parallel judicial system that relied on Roman canon law and inquisitorial procedure without a jury.

It was the Chancellery Court which began to hear the petitions of former villeins (copyholders by mid-16th century).$^{70}$ The royal courts began to receive manorial customs $^{71}$ and award protection to dispossessed copyholders who could have become the poor class but for this judicial protection and "pro-peasant" laws. ${ }^{72}$ The number of the poor increased but not so quickly. ${ }^{73}$ A slower pace of dispossession gave the peasants more time to adapt and to become leaseholders, yeomen or wage workers. Some laws

68 Trevelyan, G. M., English Social History: A Survey of Six Centuries-Chaucer to Queen Victoria, 1946, p. 60-61. URL: https://archive.org/details/in.ernet.dli.2015.219828/page/n1 23/mode/1 up?q=1550.

69 Churchill, W., A history of the English-speaking peoples. 2. The New World. Cassell, 1956, p. 23-24.

70 See Vinokurova M.V., The world of English manor. - Moscow, 2004, S. 263, Lavrovsky V.M. Research on the agrarian history of England in the 17th - 19th centuries. - Moscow, 1966, p. 101.

71 Savin A.N., An English village during the Tudor era. 2nd ed. - Moscow, 2012, pp. 231-233.

72 The Tudors systematically passed laws with parliament to prevent the taking of land from the peasants. See, for example, in the article by V.P. Mitrofanov, Agrarian legislation of Elizabeth Tudor and the first Stuarts / published on the information portal Early Modern England and available at the link http://em-england.ru/history/economy/85-agrarzakon.html.

73 One of the important factors in reducing the number of poor (poor relief) at the beginning of the reign of the Tudors were the efforts of the Privy (King's) Council to restore law and order - it's stated in the work devoted to the study of the position of the British poor reliefs at that time. See Leonard E. M., The early history of English poor relief - Cambridge, 1900, p. 21. 
were passed to help the poor, and "gradually England became the first European country to develop a system of providing for the poor", ${ }^{74}$ which was later extended. ${ }^{75}$ As a result, the poor class has never been large enough to influence the fate of the country.

The system of justice developed by the Chancery Court became called "the law of equity". Royal officials began to consider it easier to develop a completely new system of law and administration of justice rather than to reform common law, which needed updating by that time. ${ }^{76}$ The Lord Chancellor could rely on the royal prerogative and issue injunctions which disabled the judgements of the common law courts. This means that the Chancery put the king above the existing common law courts. Parliament considered this despotic and a confrontation began in 1615 .

The Chief Justice of the King's Bench at that time was Sir Edward Coke. The injunctions of Lord Chancellor Ellesmere provoked his reaction which Frederic Maitland described as follows: "Coke declared that the person receiving such an injunction is guilty of an offense under the Statute of Praemunire, ${ }^{77}$ as it casts doubt on the decisions of the royal courts in other courts". ${ }^{78}$ Ellesmere addressed himself to James I, who supported the Chancellor, since the king considered it to be his prerogative to review the decisions of the common law courts. Coke refused to recognize this and ultimately lost his position as the Chief Justice. He was elected to Parliament where he helped a group of parliamentary jurists to develop the doctrine that all judgements of the courts are supreme and both Parliament and the king must obey them.

The conflict between the king and Parliament could have escalated but the king needed taxes that he could get only with the approval of Parliament, and so he arranged for an unwritten compromise: the correlation between common law and equity turned into the relationship "between the code and the supplement to it, or between the text and the commentary". ${ }^{79}$

This compromise was not easy. In 1641, Coke 's idea of the supremacy of common law became the law, but "this great principle, that the law is above the executive, was indeed violated during the revolutionary period of the Commonwealth and Protectorate. But it re-emerged at the Restoration and was confirmed at the Revolution of 1688". ${ }^{80}$ Between 1642 and 1660 "this astonishing attempt of [...] Parliamentary leaders to wrest power from the Monarchy" 81 brought the country to the brink of dictatorship. "But even during this period, common law and the lawyers were strong [...].

74 See, Trevelyan, op.cit. p.113.

75 For more details, see, for example, Yu.E. Barlova, The social assistance system in England XVII - first half. XIX century. and the construction of narratives about the "old legislation on the poor" // Dialogue with time. Almanac of Intellectual History, 2009, No. 28, p. 297-318.

76 David, R./ Brierley, J. E., Major legal systems in the world today: an introduction to the comparative study of law. London, Stevens \& Sons, 1985, p. 326.

77 Statute of Praemunire is an Act of Parliament passed in 1393, which declared it a felony to try to challenge decisions of the common law courts in other courts.

78 Maitland F.W., Equity also the Forms of Action at Common Law - Cambridge, 1910, p. 9-10.

79 Ibid P.156.

80 Trevelyan G. M., op. cit. p. 245.

81 Ibid. p.233. 
The lawyers were too many for him [Cromwell]". ${ }^{82}$ The rule of law prevailed during the Restoration and the Glorious Revolution of 1688. All extraordinary courts established by Henry VII, except for the Chancery Court and the courts of equity, were abolished. Initially, the common law courts and equity courts functioned separately, but later they were merged during the Judicial Reform of 1873/75 and the unity of the justice system of England and Wales was restored.

For a long time, the supremacy of common law was undisputed, but at the turn of the 18th century it fell under critique. Jeremy Bentham claimed that the main function of the government was to maximize benefit of the people, the so-called common good. ${ }^{83}$ The spontaneous activity of the courts - say, if a person comes to the court with a dispute, then the court deals with it, if a person does not, the court does nothing - did not match this basic function. According to Bentham, there was no benefit from the supremacy of such a causal law. These ideas of Bentham found many supporters, and it has stimulated statutory legislation in England since the mid 19th century. The statutes organized English law and made a chaotic judicial system more structured. In the 20th century, society faced daunting problems that could only be resolved through legislation. Social security, housing, mandatory insurance, the stability of financial institutions - all these issues were not for the common law courts alone. ${ }^{84}$

However, common law and equity survived in judicial precedents and developed along with the new legislation. English constitutionalist Peter Bromhead once compared "common law to a wall to which bricks are constantly being added (in the form of new decisions of courts creating precedents) and on which new notice are stuck (representing the statutes). ${ }^{85}$

A typical example of how English common law protects a person is the case of James Somerset. ${ }^{86}$ English captains bought slaves in Guinea, brought them to an English port and immediately sold and shipped them to the colonies. ${ }^{87}$ One of these slaves was imprisoned on a ship afloat on the River Thames. When this became known, those who protested against the slave trade addressed the Court of the King's Bench with a request to issue the writ of habeas corpus to the captain of that ship. ${ }^{88}$ The writ was sent to the captain (even though he was a private person). The slave was brought to court and Lord Mansfield - the judge in this case- - held that his detention

82 Ibid., p.246.

83 Bentham J., An Introduction to the Principles of Morals and Legislation. - Oxford, 1879, P.13-14 URL: https://archive.org/details/in.ernet.dli.2015.109615/page/n5/mode/2up?q=en glish+common+law.

84 Zweigert, K./ Hein K., Introduction to comparative law, translated by T. Weir. vol. 1. Oxford: Clarendon press, 1998.

85 Bromhead P., Britain's Developing Constitution. - London: 1974, p.130.

86 The Case of James Sommersett, a Negro, in a Habeas Corpus, King's Bench: 12 Georg III, AD 1771 - 72. In: A Complete Collection of State Trials, compiled by TB Howell Esq. FRS FSA, Vol. XX - London, 1816, P. 1-81.

87 Trevelyan G. M., op. cit. p.135.

88 This order (writ habeas corpus) is issued when a person is detained by any official and contains an order to immediately bring the detained person to court to decide his fate. For more details see Dicey A.V. Introduction to the study of the Law of Constitution. - London, 1902, p. 209, 212- 218. 
was unlawful as English common law had never recognized slavery. The judgement read: from the moment the slave entered Great Britain, he was free.

Today, English lawyers manage to preserve the legal system and to maintain public trust in the law largely due to the fact that a significant part of the population have considered English law useful for almost eight centuries.

Muslim Law in the Ottoman Empire. We have already mentioned one serious shortcoming of the Muslim fiqh - the questionable effectiveness of its rules. In theory, Muslims should follow them voluntarily since they based on the authoritative sources (the Quran and the Sunnah of the Prophet). However, the mujtahids and the jurists (fakikh) of the same school disagreed on many issues after the "closing of the gates of ijtihad". Bernard Weiss describes litigation over dividing an inheritance where the litigants obtained different opinions from different fakikhs of the same madhhab and were unable to compromise. ${ }^{89}$

There were also problems with the execution of the decision of Muslim judges (qadi), since they were not assisted by any officials. The governors of the Caliph were supposed to enforce the decisions of qadis, but they could refuse to do so if they considered a decision to be wrong. ${ }^{90}$ In addition, early qadis were appointed by the Caliphs and pronounced their judgements on the basis of their discretion and, apparently, local customs. ${ }^{91}$ These problems were not solved even after the Abbasids tried to win the loyalty of famous faqihs by recognizing their decisions (fatwas) as a valid argument for qadis. ${ }^{92}$

Famous fakikhs upheld the legitimacy of the rulers but maintained their independence as guardians of Sharia and valuable middlemen between local communities and the ruling elite. ${ }^{93}$ Caliphs and secular rulers could only recognize their authority and provide funding for madrasas, which became the main centres for the study of Sharia in the Middle East, similar to universities in medieval Europe. A teacher of a madrasa enjoyed high prestige and studying at a madrasa opened up career opportunities.

89 Weiss B.G., op.cit. p.137-140.

90 Judging by Al-Khushani's "The Book of Judges (of Cordoba)", the emirs more than once tended to reconsider the "final" decision of the qadi or to obstruct its implementation. In one of these cases, Emir al- Khakam almost succumbed to the persuasion of his friend to cancel the Qadi's ruling on the return of the seized land by force. Only the conscientiousness of the judge and, possibly, the intervention of Allah returned the emir to prudence, he "did not obstruct the judge and made sure that his sentence was carried out". See: Al- Khushani. The Book of Judges (of Cordoba). Transl. from Arabic by K.A. Boyko. M., 1992. p. 54-55.

91 Coulson N. Conflicts and tensions in Islamic jurisprudence. Chicago and London, 1969. P. 4-5.

92 For the regions of the Middle East with the Hanafi madhhab, see : Tsafrir $N$., the History of an Islamic school of law: the early spread of Hanafism. Cambridge, Mass., 2004. For the Emirate of Cordoba see: Al- Khushani. The book is about judges, op. cit., p. $51 \mathrm{f}$.

93 For example, the emirs of Cordoba, when they abandoned the caliphate, needed the support of the fuqa and the emirs were forced to reckon with them. "The Book of Judges (of Cordoba)" shows how "in the role of defendants before the guardians of religious law... are representatives of the clan aristocracy and high officials, sometimes even the offspring of the ruling dynasty". See: Boyko K.A. Foreword, in: Al- Khushani. The book is about judges. op.cit., p.13. It also describes a case when a Cordoba judge makes a decision against the will of the emir al- Hakam (pp. 51-55). 
Soon after the conquest of Constantinople in 1453, the Ottoman Empire became the leading power in the Islamic world, not least due to the bureaucratic methods of government and justice. It required Suleiman I the Lawgiver (1520-1566) to reform the administrative and judicial system, as well as madrasas for training professional lawyers. As a result, a strict hierarchy of officials and departments was established. Suleiman I introduced 11 ranks of madrasas and lawyers. ${ }^{94}$ There was no practical difference between the officials and teachers of madrasas receiving their salaries from the state. Learning and teaching in a madrasa could be the starting point for a judicial career under the control of the government (the Sublime Porte).

The incorporation of teachers into the hierarchy of officials and other reforms of Suleiman I and his successors were not aimed at asserting the ideology of the rule of law or in any way limiting the powers of the Sultan and Caliph. The qadis felt their dependence on the government. Examining the limits of their independence, Ronald Jennings noted: "The imperial power could easily overshadow or suppress the authority and initiative of (any) qadi. The Porte appointed and dismissed them at will, established the boundaries of the judicial districts and maintained regular correspondence. Few qadis would dare [...] to confront its anger". ${ }^{95}$ The qadis were obliged to make a decision in accordance with the official doctrine (madhhab of the Hanafis) and the decrees of the Sultan, who appointed and removed them at his own discretion. ${ }^{96}$ This solved the problem of the enforceability of Muslim law, but hardly contributed to the independence of the judges.

Although the ideology of the rule of law did not exist, the population of the Ottoman Empire trusted and respected the legal system. Haim Gerber studied the records of the qadis of the cities of Bursa and Istanbul in the 17th century and concluded that qadi justice in the Ottoman Empire of this period was based on well-known and understandable Muslim law: "This entire body of law was perfectly known to the litigants [...]. In every case I examined I could identify the law on which the qadi was basing himself. Hence, I conclude that qadi justice in the area of my study was, in fact, very predictable". ${ }^{97}$ Considering the dependence of the qadis on the administration, he noted that "most legal disputes in the court record of seventeenth-century Bursa show not only that citizens were not easy prey at the hand of state officials, but that in most cases common people won the case". 98

The relevance of due process is well illustrated by a case in which a person was suspected of making silver items in his house, which was prohibited. "One might expect [the investigators] just to have gone ahead and searched the place, but instead they asked the court to authorize their breaking into the house and searching it". ${ }^{99}$

94 Winter M. Ottoman legal profession, in: The Oxford international encyclopedia of legal history, by S. Katz (ed.). Oxford, 2009. Vol. 4. p. 72-73.

95 Jennings R.C., Limitations of the Judicial Powers of the Kadi in 17th c. Ottoman Kayseri // Studia Islamica. 1979. No. 1 (50). p. 151.

96 Winter M., Ibid.

97 Gerber H., State, society, and law in Islam Ottoman law in comparative perspective. Albany, 1994. p.177.

98 Gerber H., Ibid, P.139.

99 Gerber H., Ibid, P. 139. 
Haim Gerber also turned to "Shikayet Defteri", 100 where he found several complaints about the violent actions of officials, which were declared illegal without qadi authorization. ${ }^{101}$ The content of one of the complaints was, what we call today, the challenge of a judge. ${ }^{102}$ The motion was accepted. In the words of Gerber, these "complaints highlight quite clearly the implied contractual ties that were the basis of sultan-citizen relations, and the obligation of the sultan to uphold the concept of [...] social justice — that is, immunity of the [...] state's subjects from illegal treatment, especially at the hand of officials". ${ }^{103}$

Summing up his research, Haim Gerber calls the situation in the Ottoman Empire in the 17th and 18th centuries "Sharia's supremacy". ${ }^{104}$ We believe that this is not about the ideology of the rule of law, but about the social norm of trust in the law. Obviously, this social norm survived precisely because the community of lawyers and judges did not lose through bureaucratization their substantial independence to develop and apply the Muslim "law of scholars". Under Suleiman I, the head of all educational institutions and the community of lawyers was the chief mufti (sheikh ul-Islam), who was not formally part of the government or any other department and, thus, retained the status of an independent arbiter in Sharia matters. ${ }^{105}$ Until the beginning of the 20th century, the leading jurists of the late Hanafi madhhab compiled doctrinal guidelines and collections of expert opinions (fatwas), and discussed legal problems in madrasas. They emphasized that in order to understand and apply Muslim law, quadis had to know not only the practical guidelines and collections of decrees, but also the leading commentaries on them. The content of the commentaries reflected a critical attitude towards the legal policy of the sultans (its interpretation and assessment were not always positive). ${ }^{106}$ The madhhab methodology featured flexible methods of the rational interpretation of Sharia and a wide range of arguments which let the qadis to enjoy considerable discretion when deciding particular cases.

Ius commune and the legitimate monarchy in France. Through the Roman canonical ius commune, Europeans learned three ideas fundamental to the rule of law. First, many conflicts (both in political and in daily life) can be expressed in legal terms, deduced by rational methods from the legitimate sources. Secondly, the authoritative and rational system of rules created by such methods is not only a means for resolving conflicts, but the legitimate framework for everyone, including the government. Thirdly, this system of rules is created, developed and implemented by a professional community of lawyers (judges, jurists, professors) who enjoy a certain degree of independence. Later, peaceful dispute resolution necessarily involved lawyers. Conver-

100 Book of Complaints, in which citizens complain to the ruler about officials. The book of complaints studied by $\mathrm{H}$. Gerber collected 2,800 complaints for 9 months in 1675 See Gerber H. Ibid, P.22.

101 Gerber H., Ibid, P.170.

102 Gerber H., Ibid, P.156.

103 Gerber H., Ibid, P.154.

104 Gerber H., Ibid, P.173.

105 Itzkowitz N., Ottoman empire and Islamic tradition. University of Chicago Press, 2008. p. 57-58.

106 Ayoub S.A., Law, Empire, and the Sultan: Ottoman Imperial Authority and Late Hanafi Jurisprudence. Oxford, 2019. p. 154. 
sely, when lawyers were involved in resolving a conflict, it was resolved peacefully. ${ }^{107}$

The history of the French kingdom from the 16th to the 18th centuries provides evidence of how important lawyers became in continental Western Europe. Despite political centralization, bureaucratic government and personal monarchy since the 16th century, the legal community continued to contribute to the development of the law as a means of resolving conflicts and limiting the arbitrariness of the authorities. ${ }^{108}$

Up to eighteen parliaments (with the Parliament of Paris setting the lead) functioned in the kingdom. They were the highest royal courts in the respective regions, but also the registrars of royal decrees. If the decrees did not comply with the fundamental laws and customs of the kingdom, the parliaments refused to register and apply them (this right being called remontrance). ${ }^{109}$ The king and the parliaments clashed over this right more than once from the 16th to the 18th centuries. ${ }^{110}$

Litigation in the royal courts was arranged after Roman-canon law and required special legal knowledge for both judges and lawyers, which they received at university. ${ }^{111}$ According to the Russian medievalist Pavel Uvarov: "At the beginning of the 16th century, the French king commanded a more developed state apparatus than his neighbours. But this apparatus can hardly be called "bureaucratic". It was rather a judicial one [...]. In 1579, the Treasurer of the Accounts Chamber [...] published a treatise which presented the structure of the royal government as a "tree of justice" [...]. In the 16th century, the French monarchy can rightfully be called the monarchy of

107 In 1551, when a conflict arose between Pope Julius III and the French king Henry II, the famous lawyer Charles Desmoulins wrote a treatise, from which it followed that the supremacy in the affairs of the French church belonged to the kings of France and the pope retreated. When the book was presented to the king, it was said: "Sire, your Majesty, with thirty thousand people, could not force Pope Julius III to peace, this little man did it with the help of this little book". See Cormier T. Rerum gestarum Henrici II, regis Galliae libri quinque. Paris,1667. P.F74. Cit. by Uvarov P.Yu., Under the arches of the palace of justice. Seven legal collisions in France of the XVI century., M., 2017, p. 32.

108 Krynen J., L 'État de justice. France, XIIIe-XXe siècle. Vol. 1. L'idéologie de la magistrature ancienne, Paris, 2009.

109 Dawson J.P., The oracles of the law. Michigan, 1968. P. 365-370; Chaline O., La pratique des remontrances au XVIIIe siècle - Paris, Rouen, Rennes // Annales de Bretagne et des Pays de l'Ouest. Anjou. Maine. Poitou - Charente. Touraine, nos 122-3, 31 octobre 2015. P. 89-105 https : // doi. org /10.4000/ abpo.3117 (date of access - 14.2.2021) In the 18th century the Parliament of Paris used this right so often that the collection of his remontstrations amounted to 8 volumes! See : Flammermont J. (ed.) Remontrances du Parlement de Paris au XVIIIe siècle, recueil de remontrances en 8 vol. P aris, 1888-1898 (available at gallica.bnf.fr).

110 Louis XIV abolished this right of the Paris Parliament, but after his death in September 1715, Philip II, Duke of Orléans, restored the right to remonstrate the Parliament of Paris in exchange for his recognition as regent of the kingdom under the young Louis XV, contrary to the will of his great great-grandfather. See : Dawson J.P. The oracles of the law. Michigan, 1968. p. 368-369; Chaline O. Op. cit. P. 94 f.

111 Dawson J.P., The oracles of the law. Michigan, 1968. P. 339 f. 
justice (la monarchie de justice)". ${ }^{112} \mathrm{He}$ adds: "In the 16th century, the French complained about the abundance of judges, those "fluffy cats" according to François Rabelais, but at the same time, they sued each other very often, to the surprise of foreigners". ${ }^{113}$

Uvarov further describes a case where a resident of Saint-Aignan near Rouen, opposed "powerful rivals: the lord of the town, the chairman of the investigative commission and its prosecutor, and the sovereign curia - the Parliament of Rouen". He and his agent "submitted multiple appeals, challenged judges, filed counterclaims, took advantage of the conflicts between the courts, and appealed to the king himself. They stalled for more time in an obviously unequal struggle, and, as it turned out, it was not in vain". As a result, the case ended up in the newly established royal court, which ruled in favour of the plaintiff. ${ }^{114}$

The positive law of Northern France during the absolute monarchy was mainly customary. ${ }^{115}$ The kings did not interfere in this area but encouraged the collection and editing of customs by royal officials and lawyers. They took advantage of their legal education to arrange casuistic customs, turned them into written norms, made them the object of rational interpretation in parliaments, and filled them with the doctrines of learned law. By the 16th century, all the customs of the kingdom were recorded, interpreted and cleaned from "bad customs". In the 18th century, lawyers tried to find general principles in customary law. ${ }^{116}$ Arguments from Roman law were also helpful to win cases. ${ }^{117}$

Having examined seven legal cases from 16th century France, Uvarov concludes that the main resource of the people of that time was "the sense of their own legal capacity, and this was possible only in a society that could be described in no other way as based on the rule of law". ${ }^{118}$ Let us add that this feeling was largely due to the legacy of the ius commune, created by lawyers four centuries earlier.

The unsuccessful attempt of Russian lawyers to establish the rule of law. As stated above, the law of the authorities functions in a way that it cannot establish the trust of the people. At the turn of the 19th century, Russian lawyers tried to change this situa-

112 Uvarov P.Y., op. cit., p. 13. A lawyer could call the monarchy legal (l'état de justice means "rule of law").

113 Ibid. P. 15.

114 The whole case is described in: Uvarov P.Yu., op. cit. p.91-111.

115 Dawson J.P., Op. cit. P. 263-272.

116 A model for understanding couture law was Charles Dumoulin's commentary on the Couture of Paris (1539), which reflects a high level of doctrinal understanding of customs compared to their first records. See: Thireau J.-L., Charles du Moulin, 1500-1566: étude sur les sources, la méthode, les idées politiques et économiques d'un juriste de la Renaissance. Genève: Librairie Droz, 1980; Lysenko O. L. Kutyumy Bovezi v sisteme istochnikov prava mediaeval'noy Franciiii vv. [Bovezi's Couture in the System of Sources of Law in Medieval France of the XIII century]. Series 11. Right. 2013. №1. URL: https://cyberleninka.r u/article/n/kutyumy-bovezi-v-sisteme-istochnikov-prava-srednevekovoy-frantsii-xiii-v (accessed 16.2.2021). An example of a generalization of couture law is the work of the lawyer of the Paris Parliament, F. Bourjon: Bourjon F. Le droit commun de la France et la coutume de Paris réduits en principes. Paris, 1747 (available online gallica.bnf.fr).

117 Uvarov P. Y., Op. cit. P. 19-37.

118 Uvarov P. Y., Op. cit. P. 226. 
tion by creating independent courts and fair trials within the legal system based on the law of the authorities. The attempt failed, but this very failure allows us a better understanding of how the social norm of the rule of law functions and what disturbs it. Let us briefly consider the social history of this attempt by Russian lawyers.

Just as in China, in Russia before the Great Reforms of Alexander II, a considerable part of Russia's rural population (serfs) had to resolve their conflicts in the private jurisdiction of their landlords. Even for the rest of the subjects, justice was not separated from administrative activities under the law of the authorities. Catherine II made some attempts to separate these functions, ${ }^{119}$ but mostly for the sake of appearance. ${ }^{120}$ Just as in China, the Russian emperors did not trust the courts, and "lawyers, as private individuals who could manipulate the law, appeared even more dubious in official eyes". ${ }^{121}$ The idea that the law should serve not only the government, but also the people, was never put into practice, although this idea was not unfamiliar to the upper echelons of the Russian government. ${ }^{122}$ The Russian authorities copied the law not from the East, but from the West. They wagered on the bureaucracy with a European education, and so the history of legal education in Russia began with the reign of Peter I. ${ }^{123}$

The first half of the 19th century was the formation period of Russian legal education, based on several large universities and specialized legal educational institutions. ${ }^{124}$ Richard Wortman describes a group of well-educated lawyers who served in the legal departments at the beginning of the Great Reforms of Alexander II as follows: "They believed in the moral dignity of their calling: that true jurists should be worthy of trust. [...] The pre-eminence of the executive in the Russian autocracy af-

119 For example, in paragraph 82 of the Law on the Provinces of 1775 (URL: https://constitution.garant.ru/history/act1600-1918/2350/) said: "The sovereign governor is not a judge".

120 For more information, see Blinov I., A. Judicial system and judicial orders before the reform of 1864 // Judicial statutes of November 20, 1864 for fifty years. T. I. Petrograd, 1914, P. 6-8.

121 Wortman R. S., The Development of Russian Legal Consciousness - Chicago - London, 1976, P.11.

122 The most famous examples of these ideas are the "Order" of Catherine II in 1767, in Article 33 of which we read: "It is necessary that the laws protect as much as possible the safety of each individual citizen" See the Order of the Empress Catherine II, given to the Commission on the composition of the draft of the New Code / ed. [and with a preface by N. D. Chechulin]. - St. Petersburg, 1907, p. 7 and the project of M. M. Speransky, carried out on the instructions of Emperor Alexander I, which explicitly states "The general subject of all laws is to establish the attitude of people to the general security of persons and property". See the Plan of state Transformation of Count M. M. Speransky - M., 1905, P. 8.

123 Tomsinov V. A., Development of jurisprudence in Russia [Development of Russian Law in the Second half of the XVII-XVIII centuries]. Ed.: Skripilev E. A.-M., 1992, P. 51-64.

124 At the suggestion of Prince P. G. of Oldenburg and M. M. Speransky, the elite Imperial School of Jurisprudence was established in 1835, whose graduates played a major role in the judicial reform of 1864. For more information about this School, see Pashenny N., Imperial School of Jurisprudence and Jurists during the years of Peace, War and Turmoil. - Madrid, 1967. There is also access to the book in electronic form URL: https://genrogge.ru/isj/ (accessed 9.2.2021). For the study in this School and the activities of its graduates, see Wortman R. S., Op. cit. P.204 ff. 
fronted their own notions of the stature of judiciary". ${ }^{125}$ The Russian government helped this professional group to emerge in order to rule by law. But these lawyers were ready to introduce and maintain the rule of law.

The abolition of serfdom changed the legal status of over 20 million peasants and also affected the nobility. From a legal point of view, the nobility became citizens on equal footing with the peasants and faced the need to protect their rights in courts. Unfair, crooked, administration-dependent courts became a serious obstacle even for them. "By the time of the accession to the throne of Emperor Alexander Nikolaevich, there was no other institution in our (social) life so much discredited and unfit as our judiciary". ${ }^{126}$ The people needed the speedy and fair administration of justice. In many provinces the nobility voiced the need for courts free from the pressure of the executive. ${ }^{127}$ In addition, there was the problem of loans secured by land which could not be resolved without fair justice. The officials reported this to the emperor ${ }^{128}$ and economists also discussed it. ${ }^{129}$

Thus, after abolishing serfdom, Alexander II found himself under pressure from the nobility who lacked peasants and needed new courts. Noble society was organized into assemblies and had many supporters among the powerful bureaucrats, so the emperor could not ignore their opinion. The professional community of lawyers was also ready and willing to create fair and independent courts. This community had its own agents of influence in the upper echelon of the executive who pushed the emperor towards reform. The draft of the judicial reform of 1864 was undoubtedly the creation of Russian lawyers.

As a result, the judicial reform of Alexander II was declared in 1864. It is essential to investigate the attitude of the emperor to this reform. He granted his people a new court and expected them, at least, to be grateful and willing to support the autocratic control over the judiciary. ${ }^{130}$ A large part of the population though the same way as the emperor. The source of such an attitude was the still popular image of a

125 Wortman R. S. Op. cit. P.234. The entire eighth chapter of R. Wortman's book is devoted to the emergence of this group, the history of the formation of their self-awareness as servants of the law, their appearance in the Russian bureaucracy and their promotion up the power vertical.

126 Blinov, I., A. Judicial system and court orders before the reform of 1864 // Legal statutes of November 20, 1864 in fifty years. T. I. PG., 1914, P. 40.

127 About this: Karelin A. P., Nobility in post-reform Russia 1861-1904, M., 1979, p. 242, and Blinov, I. A., Op. cit. P. 75-76.

128 Bezobrazov V. P., Report on the activities of the business manager of the commission, the highest established for the organization of zemstvo banks - St. Petersburg, 1861, P.41.

129 Gechevich L. V., Pozemelny kredit i zemskiye banki [Land credit and zemskiye banki] // Russian Bulletin, 1861, No. 6, vol. 33, pp. 241-307. This article is mainly economic, but it also mentions the need for judicial reform: "Arrange a solid mortgage system, eliminate the inconveniences of the current legal proceedings - this will generate trust, the hidden capital will now be discovered and revived". Ibid., p.294.

130 This attitude of the emperor to the reform can be seen, for example, in the following episode: "The Emperor was informed about the participation of one of the cassation senators in the stormy meetings of the Petrograd Zemstvo.... The emperor angrily demanded that Zamyatnin dismiss Lyuboshchinsky from the Senate. Zamyatnin reported that under the new judicial institutions, members of the courts enjoy the right of irremovability: "But not for Me," the Emperor exclaimed. The decree on the dismissal of the senator 
patriarchal government, caring for its subjects and protecting them from hardships. Most Russians (including the top officials) would find it strange that the government itself should respect the rights of the people who, in turn, were entitled to demand and receive protection from the abuses of the authorities. This view quickly clashed with the practice of the reformed courts, independent of the executive, the behaviour of lawyers in the Ministry of Justice, and the creation of a professional bar.

During this period, a political force emerged in the country which did not want to compete for power within the law and did not seek compromises. They set about overthrowing the authorities through violence and terror. A series of political trials followed where the government counted on the assistance of the courts. The main feature of those trials "was not that the government cynically used the courts for political purposes (it was quite typical of political justice), but its unwillingness to consider what was necessary to convince the court". ${ }^{131}$ The government thought itself to be above such considerations. It led to very lenient sentences for the members of Sergey Nechayev's nihilist group, the acquittal of most of the accused in the so-called "trial of 193", and finally, the acquittal of Vera Zasulich. ${ }^{132}$

Remarkably similar things happened in the financial administration where the officials considered themselves to be not "contractors who were obliged to comply with the terms of contracts, but the authorities that commanded obedience (from their contractual counterparties)". 133

As a result, the government began to consider the reformed courts as an obstacle to the order. The provincial administration was also dissatisfied with the independent courts and reported accordingly to the central authorities. ${ }^{134}$ All this gave an impetus to the counter-reform, ${ }^{135}$ and 50 years after the judicial reform, the famous Russian

was delivered to the Sovereign after this but was returned unsigned " See Kulomzin A. N., Dmitry Nikolaevich Zamyatnin-Pg, 1914, P. 99.

131 Wortman R. S., Op. cit. P.280.

132 About this: Koni A. F., Collected works in 8 vols. T. 2-M., 1966, PP. 64-79.

133 Printz N. G., Random Events that influenced the judicial transformations of 1864 // Journal of the Ministry of Justice, 1894, No. 12, p. 16.

134 Analyzing one of these notes (the Kostroma governor), Professor A. E. Nolde writes: "The thoughts expressed in the note and their motivation do not contain anything new; such comments were made in the sixties, the day after the introduction of the Statutes, and the considerations given in them that it is necessary to restore the power of the governor, as a thread uniting the separate parts of the local government, are the basis of all those arguments about strengthening the power of the governor, which supported the relevant projects in the seventies..." Relations between the judicial and administrative authorities and the fate of the main principles of Judicial Statutes in the later legislation / / Judicial Statutes of November 20, 1864 for fifty years. Vol. II. Pg., 1914, P. 625.

135 The term "counter-reform" was first used by A. A. Kiesewetter. See Kiesewetter A. A., History of Russia in the XIX century. Ch. 2-M., 1910, p. 181. A. A. Kiesewetter believed that the subsequent changes in the Judicial Statutes of 1864, brought in them "the spirit of opposite principles". A controversy has arisen around this term, which continues to our time. About this dispute, see Demichev A. A., Judicial counter-reform or the crisis of the judicial system of Russia in the 70-80 - ies of the XIX century (A new look at the solution of the old problem) // State and Law, 2012, No. 10, pp. 66-73. New Look A.A. Demicheva's idea is to consider these changes "as a transition period from one qualitative state to 
lawyer and politician Vladimir Gessen stated: "Russia is de jure a state of justice, but de facto it remains a police state". ${ }^{136}$

\section{The rule of law triangle}

Even a brief survey of the social history of law in different societies allows us to draw several preliminary conclusions.

First, people felt legally protected and the social norm of the rule of law emerged in societies where the law was treated either as a means of resolving disputes ("the law of judges") or as rules of fair, correct conduct ("learned law"). We observed this in Republican Rome, England, continental (western) Europe, and the Ottoman Empire. There was no evidence of the social norm of the rule of law in the societies run by the law of the authorities (imperial China, Rome of the Principate period, Russia before the reforms of Alexander II). In such societies most subjects sought to dodge the official law and to live by their own customs, which gave rise to legal dualism.

Secondly, the law of judges or learned law alone does not guarantee the emergence of the social norm of the rule of law or its longevity in legal consciousness. This social norm is created where and when the law of judges or learned law is accompanied by political competition, where all the participants understand the inevitability of compromise based on the law. According to Harold Berman, the need for compromise between the participants of political competition and the impossibility of a complete victory of one of them over the others created the need for the law: "From 1076 to 1122 wars were fought in various parts of Europe between supporters and opponents of the papal authority and its program. Eventually, compromises were reached. Neither side was wholly victorious. In the end, compromises were reached. It was this total upheaval that gave birth to the Western legal tradition". ${ }^{137}$ However, the cases of England, the Ottoman Empire, and Russia discussed in this article show that political competition and law caused one another: the need for compromise in political competition creates the need for laws that all parties trust, and trustworthy laws create the possibility of compromise and sustainable political competition.

Let us recall some examples from this article. In the early 17 th century England, one of the parties to the conflict (Parliament) relied on English common law and the other party to the conflict had to take this into account. As a result of the compromise, common law was corrected with the help of the law of equity, which restored confidence in the law. The sultans of the Ottoman Empire also took advantage of a developed legal system, which enjoyed people's confidence, to strike the right balance between the central government and local communities. This paved the way for the steady development of the Ottoman empire. In late 19th-century Russia, it was not

another: from the model of the Judicial Statutes of 1864, largely speculatively compiled by their authors, to judicial legislation that is actually adapted to the Russian state system and corresponds to the Russian mentality". p. 73. One can say this, but it does not change the meaning that A. A. Kiesewetter put into his term.

136 Gessen V.M., On the judiciary, in: Judicial reform / ed. N.V. Davydov and N.N. Polyansky. Vol. 1. M., 1915, P. 14.

137 Berman H.J. op. cit., p. 520. 
possible to replace the law of the authorities with learned law and to develop a social norm of the rule of law among people precisely because of the lack of trust in the law on all sides of political competition and the non-existent habit of living according to the law of Russia at the end of the 19th century. Thus, the link between political competition and the law that people trust is two-sided.

Third, public confidence in the legal system is impossible without a professional group of lawyers. The need for law creates the need for lawyers, and a professional group of lawyers - for whom trustworthy law is the basis of their existence - develops and improves the law. As the French sociologist Pierre Bourdieu wrote: "It is the professionals who create the need for their own services, transforming problems expressed in ordinary language into legal problems. There is no doubt that they are driven by financial interests in the construction of conflicts, but also by their ethical or political dispositions". ${ }^{138}$ It is important that this professional group develops the law independently of public authorities, although it can formally be part of it (as it was in the Ottoman Empire, late Imperial Rome, and France in the 16th-18th centuries). Even trustworthy law can become the law of the authorities and loses people's trust, if there is no political competition and no lawyers developing the law independently of the authorities.

A stable regime that creates and maintains the social norm of the rule of law in the legal consciousness of the people can be explained by a triangle (see Figure 1). It indicates the necessary elements for the stability of the social norm of the rule of law. Its stability weakens in the absence of one element of the triangle. This triangle existed in the Roman republic for about four centuries, but one missing element led to the loss of balance and the rise of the authoritarian rule of the Dominate. Why did this happen? We believe that people have diverging attitudes toward the law. For some groups, the social norm of the rule of law - this "weight" on the scales of decisionmaking - outweighs the problems they cannot solve within the existing legal system. Other social groups either have no social norm of the rule of law at all, or the problems of this group outweigh the "weight" of the rule of law on the scales of decisionmaking. If the second group becomes so significant that it manages to win the political competition (even by illegal methods), the balance of the triangle is disturbed, and the society will be at the mercy of an authoritarian or totalitarian regime (see Figure 2).

Rome experienced the clash of the Populares who had little respect for the law and the Optimates who upheld of the social norm of the rule of law. The Optimates failed to prevail over the Populares, and so authoritarian rule was established in Rome. A similar breakdown of political competition occurred in the Weimar Republic during the "conservative revolution" carried out by the National Socialist Party. It promoted the interests of a large group of people who no longer wanted to live according to the law, and so the totalitarian regime of the Third Reich emerged.

In England, the rebels under the leadership of John Ball and Wat Tyler sought to break up political competition based on the law. But the prudent politics of the Tudors did not allow this group to grow large enough to win the competition. During the

138 Bourdieu P., La force du droit: elements pour une sociologie du champ juridique. Actes de la recherche en sciences sociales. 1986, № 64. p. 11. 
French revolution, the Jacobin dictatorship of 1793-1794 emerged, but did not take hold. A series of revolutions and coups in France can be explained by the fact that the upholders of the social norm of the rule of law among the French were almost as numerous as those who did not follow this norm. Recently we have witnessed a similar situation in the US, where there is an incredibly influential group of American citizens who lost confidence in their legal system and supported the "non-systemic" leader Donald Trump in the 2016 presidential elections. However, in the following electoral cycle, the upholders of the social norm of the rule of law consolidated and asserted themselves as the majority. And yet, Americans still have something to think about. US lawyers have many complaints about the US legal system. ${ }^{139}$

Research on the comparative social history of the law of different civilizations is a fairly recent activity. Gradually, researchers are including more legal and non-legal documents into their comparisons. In this paper, we build on these results in an attempt to identify how the social norm of the rule of law arises. It brings us to two important conclusions. First, the rule of law triangle is possible not only in Western societies but wherever there is the law of judges or learned law, political competition, and a community of professional lawyers who develop and apply the law independently of the administration. Secondly, the long-term stable existence of the rule of law triangle does not guarantee that it will also remain so in the future. This is a clear signal to governments in countries where this triangle has been functioning for a long time. In the Roman Republic, it collapsed after almost 400 years, in the Ottoman Empire it lasted almost as long, until the second half of the 19th century. We have witnessed the first attack on the rule of law triangle in the US. Only England has managed to maintain the stability of the rule of law triangle for more than 800 years.

This article takes the first steps in the historical studies of the rule of law triangle. Yet, the authors of the article claim it to be productive not only for understanding the rule of law and its varieties in the past and in the present.

139 See, for example, Pizzi W. T., Trials without truth: why our system of criminal trials has become an expensive failure and what we need to do to rebuild it. - NYU Press, 2000. In this book, its author-a retired judge-shows very convincingly that American justice has turned from a fair trial into something remarkably like the game of American football. 
Figure 1. Factors that make the social norm of the rule of law stable
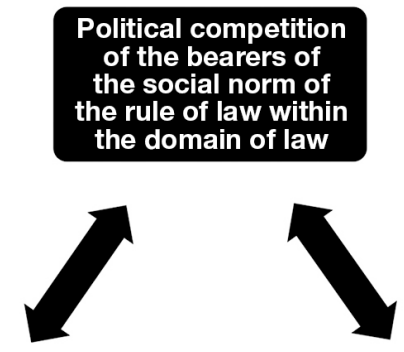

Independent professional community of lawyers

Law of the judges / learned law, made independently from the government

Figure 2. Compromised stability of the social norm of the rule of law

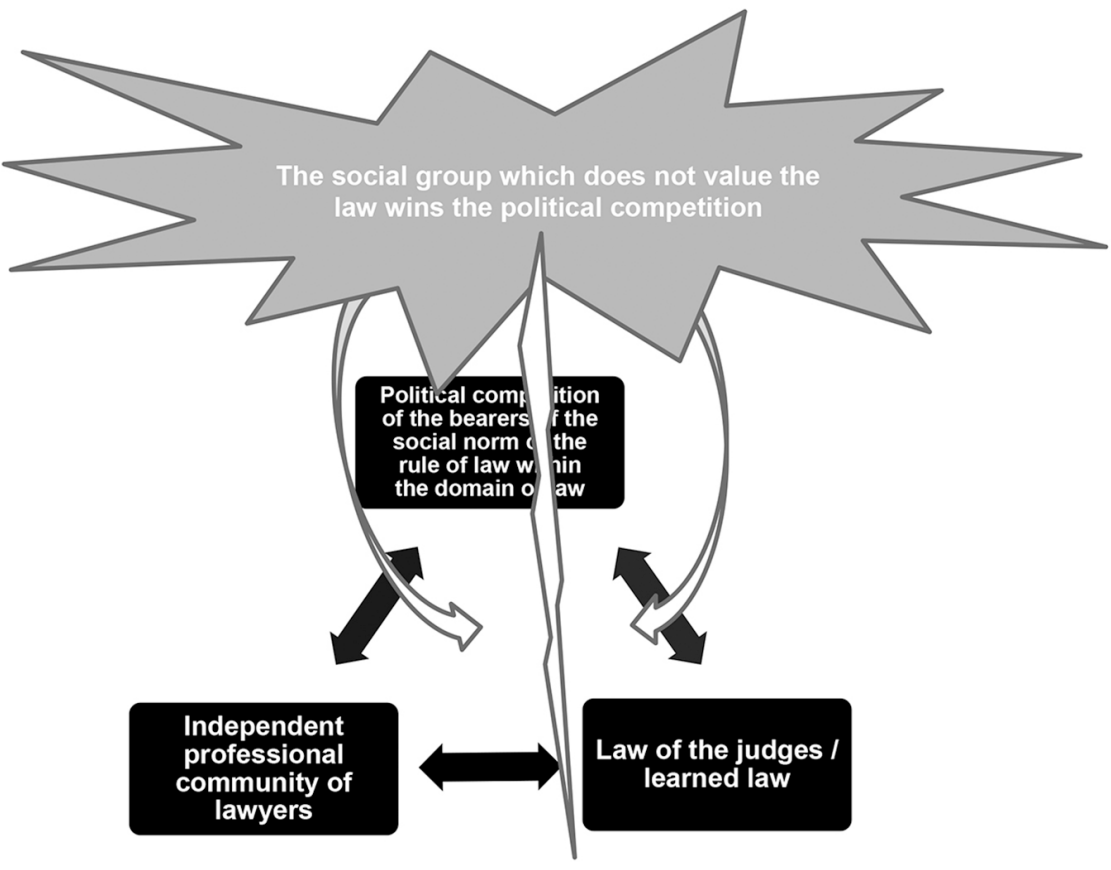

